\title{
THE STUDY OF MAIN PHYSICAL-CHEMICAL PARAMETERS OF CHAENOMELES AND PRODUCTS OF ITS PROCESSING
}

Galyna Khomych

The Department of Food Industry Technologies and Restaurant Industry Poltava University of Economics and Trade

3 Koval str., Poltava, Ukraine, 36014

homichg@mail.ru

Aleksandra Horobetc

The Department of Food Industry Technologies and Restaurant Industry Poltava University of Economics and Trade

3 Koval str., Poltava, Ukraine, 36014

antjukhvaaleksandra@rambler.ru

Yuliia Levchenko

The Department of Food Industry Technologies and Restaurant Industry Poltava University of Economics and Trade

3 Koval str., Poltava, Ukraine, 36014

yuliya12@ukr.net

Anzhela Boroday

The Department of Food Industry Technologies and Restaurant Industry Poltava University of Economics and Trade

3 Koval str., Poltava, Ukraine, 36014

borodayanzela@mail.ru

Nataliia Ishchenko

The Department of Food Industry Technologies and Restaurant Industry Poltava University of Economics and Trade

3 Koval str., Poltava, Ukraine, 36014

natad7@ya.ru

\begin{abstract}
In the article were considered the topical problems, connected with health worsening and human existence. The use of vegetable raw material as a source of biologically active components is prospective in production foodstuff. There were offered the rational methods of processing of chaenomeles for getting juice and puree. There were carried out an analysis of expedience of using chaenomeles and products of its processing for enrichment foodstuff. It was established, that maximal amount of phenol substances is contained in fruit peel and L-ascorbic acid - in flesh. It was determined, that apple acid prevails among organic ones, fructose - among sugars and phenol substances are mainly presented by procyanidins. Using chromotographic analysis in the products of chaenomeles processing were identified 48 names of aromatic compounds, alcohols, acids, ethers and unsaturated carbohydrates prevail among them. There were studied the physical-chemical parameters of fruit sauces and flour products with addition of chaenomeles processing products. The received results prove that the ready foodstuff that contain puree and juice of chaemomeles have the high organoleptic, physical-chemical parameters and also heightened biological value.
\end{abstract}

Keywords: chaenomeles, aromatic substances, biologically active substances, phenol substances, enzymolysis.

DOI: 10.21303/2504-5695.2016.00147 C Galina Khomich, Aleksandra Horobetc, Yliya Levchenko, Anzhela Boroday, Nataliia Ishchenko

\section{Introduction}

The problem of modernity is an essential health worsening and population life shortening, caused by unfavorable ecological situation, low quality of foodstuff, use of artificial feed additives and consumption of significant amount of refined products [1]. 
The result of influence of these factors is a disorder of the normal physical state of human organism, increase of quantity of oncologic and other professional diseases. The problem of children health is most urgent, because each second child is born already with certain types of allergic diseases, innate pathologies and other disorders of normal development [1].

The topical problem is creation of food products with directed biological effect at the expense of using natural ingredients of the raw material with antioxidant and adaptogenic properties.

In this connection the great social importance is gained by elaboration of producing foodstuff with improved consumer properties that provides lowering of their energetic value and rising of the food one, improvement of organoleptic parameters.

\section{Materials and methods of research}

2. 1. Standardized methods of study of physical-chemical parameters of chaenomeles and products of its processing

The mixture of species of chaenomeles fruits, harvested in Ukraine, In Poltava region, was used for studies.

The object of studies was chaenomeles, juice and puree of it and also fruit sauces and flour products using products of chaenomeles processing.

For determination of the main physical-chemical parameters the standard methods were used: dry substances were determined by the method of arbitral drying, acidity - by the method of volume titration, vitamin $\mathrm{C}$ - by iodometric method, phenol substances - by Folin-Chiocolteu method in recalculation on gallic acid [2].

2. 2. Method of chromatographic study for identification of phenol substances, organic acids, sugars and volatile compounds

For identification of phenol substances, contained in chaenomeles and products of its processing were used chromatographic studies, carried out on chromatograph of Agilent Technologies (model 1100) (USA), completed with running vacuum decontaminator G1379A, four-channel pump of low pressure gradient G13111A, automatic injector G1313A, column thermostat G13116A, diode matrix detector G1316A. For analysis was used chromatographic column with size 2,1×150 mm, filled with octadecylsilyl sorbent, granulations 3,5 mcm «ZORBAX-SB C-18».

For analysis was set the following regime of chromatography: supply speed of mobile phase 0,25 ml/min; eluent working pressure $240-300 \mathrm{kPa}$; temperature of column thermostat $35^{\circ} \mathrm{C}$; sample volume $2 \mathrm{mcl}$. Detecting parameters were set as following: measurement scale 1,0; scanning time 0,5 s. Parameters of spectrum removal: each peak 190-400 nm. Waves lengths: 280, 313, 350, 371, $254 \mathrm{~nm}$.

Identification of phenol substances was determined by the time of standards content and spectral characteristics.

For analysis were used the extracts of vegetable raw material (1:10), filtered through the membrane Teflon filter with pores size $0,45 \mathrm{mcm}$ Vial for analysis.

Determination of content of organic acids and sugars was carried out on chromatograph of Agilent Technologies (model 1100), completed with running vacuum decontaminator G1379A, four-channel pump of low pressure gradient G13111A, automatic injector G1313A, column thermostat G13116A, diode matrix detector G1316A, refractometric detector G1362A. For analysis was used carbohydrate chromatographic column with size 7,8×300 mm, «Supelcogel-C610H».

For analysis was set the following regime of chromatography: supply speed of mobile phase $0,5 \mathrm{ml} / \mathrm{min}$; eluent $0,1 \%$ water solution of $\mathrm{H} 3 \mathrm{PO} 4$; eluent working pressure $33-36 \mathrm{kPa}$; temperature of column thermostat $30^{\circ} \mathrm{C}$; sample volume $5 \mathrm{mcl}$.

Parameters of refractometric detecting: measurement scale $0,5 \mathrm{~s}$.

Detecting parameters of diode matrix detector: measurement scale $0,5 \mathrm{~s}$; wave length $-210 / 8$, comparison - 360/80 nm.

Identification of organic acids and sugars was determined by time of standards retention.

The content of volatile (aromatic) substances was determined on chromatograph Agilent Technologies 6890 (USA) with mass-spectrometric detector 5973. Chromatographic column - cap- 
illary DB-5 internal diameter 0,25 mm and length $30 \mathrm{~m}$. Speed of carrier gas (helium) $1.2 \mathrm{ml} / \mathrm{min}$. Temperature of heater of sample input $-250{ }^{\circ} \mathrm{C}$. Temperature of thermostat is programmed from 50 to $320^{\circ} \mathrm{C}$ with speed $4{ }^{\circ} \mathrm{C} / \mathrm{min}$.

For identification of components the library of mass-spectrums NIST07 and WILEY 2007 on the general number of spectrums more than 470000 in combination with programs for identification AMDIS and NIST was used. For quantitative calculations was used the method of internal standard.

\section{Experimental procedures}

For analysis of organoleptic parameters was chosen chaenomeles in stage of consumer ripeness, harvested in the middle of September on the territory of Ukraine, in Poltava region. The fruits differed by color from light yellow to the yellow (Fig. 1), had the typical sour, slightly tart flavor and rich scent corresponding to their botanical characteristics [3]
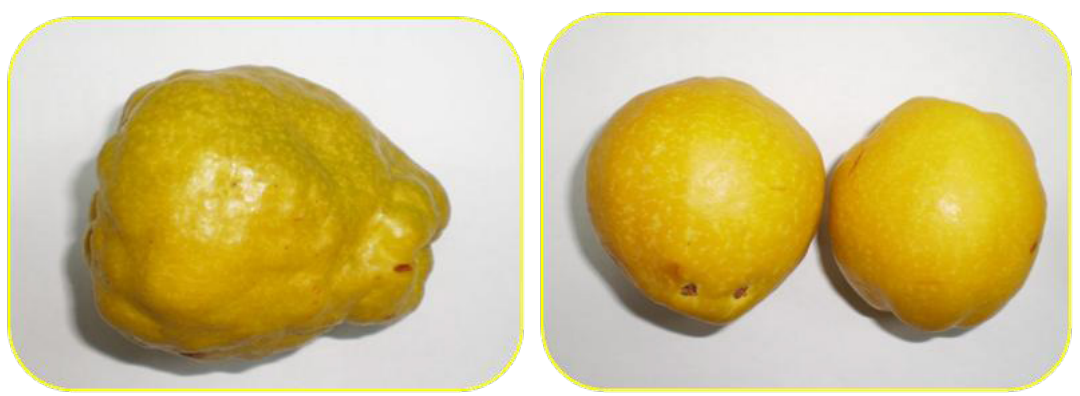

Fig. 1. Organoleptic characteristic chaenomeles fruits

Analysis of studies [3] on determination of components of chanomeles fruits and their biological value testifies that $60 \%$ of fruit is flesh containing organic acids $(6,33 \%)$, pectin substances $(1,82 \%)$, L-ascorbic acid (248 mg/100 g) and phenol substances (920 mg/100 g). Nevertheless the fruit peel (17\% of fruit mass) and seed cell (9\% of fruit mass) containing phenol substances (1400 mg/100 g) are also valuable.

The use of enzymatic preparations is the most effective method of preliminary processing of fruits and berries raw material [4]. Their use accelerates technological processes, increase juice output of the raw material and raises its nutritive value at the expense of enrichment with phenol compounds. This processing method allows except the rise of juice output, maximally extract BAS of fruits peel and flesh, although for restaurant enterprises the method of pressing is more rational [3].

The experimental studies [5] established that the high puree output and minimal amount of wastes are reached at blanching of chaenomeles fruits in water. Such method of preliminary processing is most available in conditions of restaurant [5].

In chaenomeles fruits and products of their processing (juice, puree) were determined the physical-chemical quality parameters, which results are presented in the Table 1.

Table 1

Physical-chemical quality parameters of chaenomeles and products of its processing $(n=3, p \leq 0,05)$

Quality parameters

\begin{tabular}{cccccc} 
Raw material name & Mass fraction, $\%$ & \multicolumn{2}{c}{ Content, mg/100 g of dry substances } \\
& Dry substances & Titrated acids & Pectin substances & L-ascorbic acid & Phenol substances \\
\hline Chaenomeles & 18,44 & 6,36 & 1,62 & 248,00 & 885,00 \\
Juice & 11,44 & 5,63 & 0,82 & 144,32 & 410,00 \\
Puree & 13,55 & 4,77 & 1,74 & 98,56 & 560,00
\end{tabular}

The results, given in the Table 1, prove that products of chaenomeles processing contain pectin substances, phenol compounds and L-ascorbic acid. 
For determination of biological value of products of chaenomeles processing the composition of organic acids and sugars composition was studied (Table 2).

Table 2

Composition of organic acids and sugars in products of chaenomeles processing $(n=3, p \leq 0,05)$

\begin{tabular}{cccccccc}
\hline \multirow{2}{*}{$\begin{array}{c}\text { raw material } \\
\text { name }\end{array}$} & \multicolumn{4}{c}{ Organic acids } \\
& lemon & apple & succinic & cinchona & sucrose & glucose & fructose \\
\hline Juice & 0,15 & 3,40 & 0,11 & 1,64 & 0,64 & 0,36 & 2,69 \\
Puree & 0,09 & 2,85 & 0,07 & 0,82 & 0,43 & 0,41 & 1,72
\end{tabular}

The results of the studies demonstrate (Table 3) that the main part of soluble dry substances is sugars, namely hexoses - glucose and sucrose. Fructose is a sugar, easily assimilated by organism that is why the products of chaenomeles processing can be used in technology of foodstuff of dietary and special direction.

The studies of fraction composition of phenol substances, contained in products of chaenomeles processing (Table 3), demonstrate the significant content of procyanidins with antioxidant activity 20 times more than ascorbic acid and 50 times more that vitamin $\mathrm{E}$.

Table 3

Composition of phenol substances in chaenomeles products processing $(n=3, p \leq 0,05)$

\begin{tabular}{|c|c|c|c|c|c|c|}
\hline sample name & $\begin{array}{l}\text { Groups of phenol } \\
\text { substances }\end{array}$ & $\begin{array}{l}\text { Content, } \\
\mathrm{mg} / 100 \mathrm{~g}\end{array}$ & $\begin{array}{l}\% \text { of PS* } \\
\text { content }\end{array}$ & $\begin{array}{l}\text { Dominating } \\
\text { representative }\end{array}$ & $\begin{array}{l}\text { Content, } \\
\text { mg/100g }\end{array}$ & $\begin{array}{c}\% \\
\text { of content }\end{array}$ \\
\hline Juice & \multirow{2}{*}{$\begin{array}{c}\text { Procyanidins and their } \\
\text { derivatives }\end{array}$} & & 69,20 & \multirow{2}{*}{$\begin{array}{l}\text { Procyanidin } \\
\text { trimer }\end{array}$} & 87,59 & 31,70 \\
\hline Puree & & 322,09 & 58,16 & & 157,79 & 5,83 \\
\hline Juice & \multirow{2}{*}{$\begin{array}{c}\text { Flavan-3-oils and their } \\
\text { derivatives }\end{array}$} & 116,52 & 29,19 & \multirow{2}{*}{ Epicatechins } & 64,08 & 54,99 \\
\hline Puree & & 218,59 & 39,47 & & 197,94 & 7,31 \\
\hline Juice & \multirow{2}{*}{$\begin{array}{l}\text { Oxycinnamic acids and } \\
\text { their derivatives }\end{array}$} & 5,89 & 1,48 & \multirow{2}{*}{ Chlorogenic acid } & 5,89 & 1,48 \\
\hline Puree & & 11,02 & 1,99 & & 11,02 & 1,99 \\
\hline Juice & \multirow{2}{*}{$\begin{array}{c}\text { Flavons and their deriv- } \\
\text { atives }\end{array}$} & 0,54 & 0,14 & \multirow{2}{*}{ Rutin } & 0,54 & 0,14 \\
\hline Puree & & 2,07 & 0,37 & & 2,07 & 0,37 \\
\hline
\end{tabular}

Taking into account the fact that half-finished products of chaenomeles have powerful antioxidant properties, it can be talked about the high biological value of foodstuff, prepared with them.

The study of fraction composition of volatile substances (Table 4) in products of chaenomeles processing prove its significant biological value.

The received data (Table 4) prove that the scent of juice and puree is formed by aromatic alcohols, acids, aldehydes, ketons, ethers, carbohydrates that are present in the raw material. Significant amount of volatile aromatic substances are contained in puree because the whole fruit is used at preparation, including peel - the main source of aromatic substances.

Because of significant acidity of chaenomeles puree, it is not expedient to use it in the pure form. That is why at elaboration of sauces receipts it was blended with other pectin-containing raw material: apple, pumpkin, sunroot [5].

As a result of blending of apple and chaenomeles puree in set proportions it was elaborated the receipt of sauce "Nasoloda". In the sauces samples were studied the structural-mechanical properties and physical-chemical parameters. The received sauces have the high biological value, thermal stability, viscosity comparing with control (Table 5).

The positive factor is also that the use of half-finished products of chanomeles decreases their total microbiological pollution, provides prophylaxis of potato disease development [9]. 
Physical-chemical quality parameters are presented in the Table 5, 6.

Table 4

Content of volatile aromatic compounds in juice and puree of chaenomeles $(n=3, p \leq 0,05)$

\begin{tabular}{|c|c|c|c|c|c|c|}
\hline \multirow{3}{*}{ compounds groups } & \multicolumn{6}{|c|}{ raw material name } \\
\hline & \multicolumn{3}{|c|}{ Puree } & \multicolumn{3}{|c|}{ Juice } \\
\hline & $\begin{array}{c}\text { Number of } \\
\text { names }\end{array}$ & $\begin{array}{l}\text { Content, } \\
\mathbf{m g} / \mathbf{d m}^{3}\end{array}$ & $\begin{array}{c}\% \text { of } \\
\text { total content }\end{array}$ & $\begin{array}{c}\text { Number of } \\
\text { names }\end{array}$ & $\begin{array}{l}\text { Content, } \\
\mathbf{m g} / \mathbf{d m}^{3}\end{array}$ & $\begin{array}{c}\% \text { of } \\
\text { total content }\end{array}$ \\
\hline Alcohols & 9 & 7,49 & 11,77 & 9 & 4,37 & 18,45 \\
\hline Acids & 12 & 36,24 & 56,93 & 12 & 7,67 & 32,39 \\
\hline Aldehydes & 2 & 0,60 & 0,94 & 2 & 0,56 & 2,36 \\
\hline Ketones & 4 & 0,98 & 1,54 & 4 & 1,89 & 7,98 \\
\hline Terpenes & 4 & 3,61 & 5,67 & 4 & 1,04 & 4,39 \\
\hline Ethers & 9 & 4,95 & 7,78 & 9 & 2,88 & 12,16 \\
\hline $\begin{array}{c}\text { Unsaturated } \\
\text { carbohydrates }\end{array}$ & 8 & 7,45 & 11,70 & 8 & 2,92 & 12,33 \\
\hline Unidentified & 3 & 2,34 & 3,68 & 3 & 2,35 & 9,92 \\
\hline $\begin{array}{c}\text { Total content of volatile } \\
\text { compound }\end{array}$ & 51 & & & 51 & & \\
\hline
\end{tabular}

Table 5

Physical-chemical quality parameters of sweet sauces with product of chaenomeles processing $(\mathrm{n}=3, \mathrm{p} \leq 0,05)$

\begin{tabular}{ccccccc}
\hline \multirow{2}{*}{ Sauce name } & \multicolumn{3}{c}{ Mass fraction, \% mass } & \multicolumn{3}{c}{ Content, mg/100 g } \\
& Dry substances & Pectin substances & Titrated acids & L-ascorbic acid & Phenol substances & pH \\
\hline Apple sauce (control) & 48,00 & 0,42 & 0,13 & 13,45 & 80,00 & 3,70 \\
Sauce "Nasoloda" & 53,00 & 0,81 & 1,61 & 61,60 & 260,00 & 3,50 \\
Sauce "TopiHen" & 55,00 & 1,49 & 1,68 & 61,18 & 262,00 & 3,50 \\
Chaenomeles-pumpkin & 58,00 & 1,12 & 2,56 & 62,19 & 262,00 & 3,40
\end{tabular}

Table 6

Physical-chemical quality parameters of ready products of yeast dough with products of chaenomeles processing $(n=3, p \leq 0,05)$

\begin{tabular}{cccr}
\hline Parameters & Control & \multicolumn{2}{c}{ Studied samples } \\
& & With juice & With puree \\
\hline Specific volume, $\mathrm{cm}^{3} / \mathrm{g}$ & 2,80 & 3,30 & 3,30 \\
Form stability, H/D & 0,60 & 0,70 & 0,70 \\
Acidity, degrees & 2,50 & 2,60 & 3,00 \\
Humidity, $\%$ & 38,00 & 40,10 & 41,00 \\
Porosity, $\%$ & 68,00 & 75,00 & 75,00
\end{tabular}

The results of the studies (Table 5) prove that the use of products of chaenomeles processing in the sweet sauces technology raises their biological value at the expense of increase of L-ascorbic acid, pectin and phenol substances content comparing with control.

Taking into account that chaenomeles puree contains high percentage of pectin substances and organic acids, it can be used as natural structure-creator in technology of fruit juices and pastry. 
There was determined an expedience of using chaenomeles puree in technology of flour products of yeast dough and of flour with weak gluten. Introduction of chaenomeles juice or puree in receipt of yeast dough at the mix stage favors the strengthening of dough structure and rise of hardness of gluten proteins structure that can be explained by proteins oxidation under influence of L-ascorbic acid, organic acids and complex-creation with polyphenols, contained in puree in sufficient amount [9].

Introduction of chaenomeles processing products in receipts of flour products of yeast dough (Table 6) raises porosity of ready products and improves assimilation. The humidity and acidity growth in experimental samples comparing with control allows prolong the storage terms of ready products and prevent the potato disease development.

\section{Results of research}

The results of the study (Table 4) testify to the predominance of alcohols, acids, ethers and carbohydrates among volatile compounds, presented in products of chaenomeles processing.

Alcohols are presented by unsaturated, saturated and aromatic alcohols. Combination of $\alpha$-terpineol (lilac), $\beta$-terpeniol (hyacinth), $\beta$-ionone (violet), $\alpha$-farnesene (green apple), estragole (estagon), lianol (may lily), evdesmol (rose, eucalyptus) and ethyl caprylate (flower scent) form the unique stable scent in the products of chaenomeles processing.

The special attention must be paid to squalene (representative of unsaturated carbohydrates) in amount $2,11 \mathrm{mg} / \mathrm{kg}$ in juice and $6,43 \mathrm{mg} / \mathrm{kg}$ in puree that is considered as "oxygen vitamin" and is a unique component of lipids of human skin.

Having analyzed the data of the Table 4, we established that almost $60 \%$ of the total content in puree and $30 \%$ in juice are acids. The group of acids is generally presented by carboxylic ones that have antimicrobial, antiseptic properties, immune-raising effect, help to fight against diabetes and high blood pressure. There are also linoleic and oleic acids, known as $\omega-6$ and $\omega-9$ unsaturated fatty acids that have positive influence on human organism and are used for prevention of diseases of different etiology [10].

Antimicrobial and antibacterial properties of products of chaenomeles processing allow assume the decrease of microbiologic contamination in foodstuff with chaenomeles.

Taking into account the high nutritive and biological value of products of chaenomeles processing, it is rational to use them in technologies of sweet sauces and flour pastry to improve organoleptic, structural-mechanical and physical-chemical parameters of ready products.

\section{Conclusions}

The studies of chemical composition of chaenomeles established that the raw material and products of chaenomeles processing contain organic acids, mainly apple, cinchona, lemon and succinic ones. Sugars are presented mainly by monosaccharides with predominant fructose and glucose that allow offer it in technology of foodstuff of medical-prophylactic direction. Determination of fraction composition of phenol substances demonstrated that raw material contains procyanidins, catechins, chlorogenic acid and rutin, the positive influence of these substances on human organism is proved by the medical-biological studies.

There was established the positive influence of products of chaenomeles processing on organoleptic and physical-chemical parameters of sweet sauces and yeast dough products.

Thus, chaenomeles it is a raw material that can be used in production of foodstuff with improved nutritive value and heightened antioxidant properties.

References: hyya, 1 (1).

[1] Marushko, Yu. V. (2013). Mikroelementy ta stan imunitetu v ditey. Aktual'naya ynfektolo-

[2] AACC International. Methods 10-50D and 10-52 (2000). Approved Methods of the American association of Cereal Chemists, 10th ed. AACC International, St. Paul, MN, U.S.A.

[3] Khomych,, G. P., Vasyuta V. M., Levchenko Yu. V. (2015). Kompleksna pererobka plodiv henomelesu. Naukovi pratsi Odeskoyi natsIonalnoyi akademiyi harchovih tehnologiy, 46 (2), 75-79. 
[4] Khomych,, G. P. Kaprelyants L. V., Tkach N. I. (2010). Vikoristannya fermentnih preparativ dlya pererobki plodovo-yagidnoyi dikorosloyi sirovini. Zbirnyk naukovykh prats' "Obladnannya ta tekhnolohiyi kharchovykh vyrobnytstv", 25, 123-128

[5] Khomych,, G. P. Levchenko, Yu. V. (2015). Vikoristannya henomelesu v tehnologiyi virobnitsta solodkih sousiv. Naukoviy visnik Lvivskogo Natsionalnogo universitetu veterinarnoyi meditsini ta biotehnologiy im. S. Z. Gzhitskogo, 17.4 (64), 166-174

[6] Sancheti, S., Sancheti, S., Seo, S.-Y. (2009). Chaenomeles Sinensis: A Potent $\alpha$-and $\beta$-Glucosidase Inhibitor. American Journal of Pharmacology and Toxicology, 4 (1), 8-11. doi:10.3844/ ajptsp.2009.8.11

[7] Klimenko, S. V. Mezhenskiy, V. M (2013). Pohodzhennya sortiv henomelesa (Chaenomeles Lindl.) ukrayinskoyi selektsiyi. Introduktsiya roslin, 4, 25-30.

[8] Zhang, L., Cheng, Y.-X., Liu, A.-L., Wang, H.-D., Wang, Y.-L., \& Du, G.-H. (2010). Antioxidant, Anti-Inflammatory and Anti-Influenza Properties of Components from Chaenomeles speciosa. Molecules, 15 (11), 8507-8517. doi:10.3390/molecules15118507

[9] Homich, G. P. Gorobets, A. M. (2015). Vikoristannya henomelesu ta produktIv yogo pererobki v tehnologiyi boroshnyanih virobIv. Naukoviy visnik Lvivskogo Natsionalnogo universitetu veterinarnoyi meditsini ta bIotehnologiy im. S. Z. Gzhitskogo,17.4 (64), 174-179.

[10] Scalia, S., Marchetti, N., \& Bianchi, A. (2013). Comparative Evaluation of Different CoAntioxidants on the Photochemical- and Functional-Stability of Epigallocatechin-3-gallate in Topical Creams Exposed to Simulated Sunlight. Molecules, 18 (1), 574-587. doi:10.3390/molecules18010574 